\title{
Do Crop Rotations in Rice Reduce Weed and Echinochloa spp. Infestations? Recommendations for Integrated Weed Control
}

\author{
Gabriel Pardo ${ }^{1,2}$, Ana Isabel Marí ${ }^{1}$ (D) Joaquín Aibar ${ }^{3}$ and Alicia Cirujeda $^{1,2, *(\mathbb{D})}$ \\ 1 Unidad de Protección Vegetal, Centro de Investigación y Tecnología Agroalimentaria de Aragón (CITA), \\ Avda. Montañana 930, 50059 Zaragoza, Spain; gpardos@aragon.es (G.P.); aimari@cita-aragon.es (A.I.M.) \\ 2 Instituto Agroalimentario de Aragón-IA2 (CITA-Universidad de Zaragoza), 50013 Zaragoza, Spain \\ 3 Departamento de Ciencias Agrarias y del Medio Natural, Instituto Agroalimentario de Aragón-IA2, \\ CITA Universidad de Zaragoza, 22027 Huesca, Spain; jaibar@unizar.es \\ * Correspondence: acirujeda@aragon.es; Tel.: +34-976716322
}

check for updates

Citation: Pardo, G.; Marí, A.I.; Aibar, J.; Cirujeda, A. Do Crop Rotations in Rice Reduce Weed and Echinochloa spp. Infestations? Recommendations for Integrated Weed Control. Agronomy 2021, 11, 454. https:// doi.org/10.3390/agronomy11030454

Academic Editor: Anestis Karkanis

Received: 5 February 2021

Accepted: 25 February 2021

Published: 28 February 2021

Publisher's Note: MDPI stays neutral with regard to jurisdictional claims in published maps and institutional affiliations.

Copyright: (c) 2021 by the authors. Licensee MDPI, Basel, Switzerland. This article is an open access article distributed under the terms and conditions of the Creative Commons Attribution (CC BY) license (https:// creativecommons.org/licenses/by/ $4.0 /)$.

\begin{abstract}
The species belonging to the genus Echinochloa represent the main weeds in rice fields worldwide. Heavy soils are especially appropriate for this crop that is often grown in monoculture. A drought period in 2012 impeded farmers from sowing rice in some parts of the region of Aragon (northeastern Spain) and, unusually, they seeded alternative crops such as winter cereal, fescue (Festuca arundinacea), ryegrass (Lolium multiflorum) and lucerne (Medicago sativa). A total of 20 fields were selected, in which rice had been grown in monocrop until 2011 and several crop sequences were established afterwards; weed vegetation was recorded in spring, summer and autumn 2014-16 to find out if the crop rotations reduced weed infestations. Winter cereal and fescue were the crops with the highest soil cover; ryegrass and lucerne had difficulties in installation probably due to the heavy soil textures. Echinochloa spp. plants were found in the winter cereal stubble after having grown fescue for the previous two years and rice before that; in the forage fields, small plants of earing Echinochloa spp. adapted to mowing were detected. Recommendations for Integrated Weed Management that arise from the observations are ploughing the winter cereal stubble before seed shed of the emerged Echinochloa plants, assuring a high density of the forage crops, and efficient herbicide control in rice fields.
\end{abstract}

Keywords: monocrop; mowing; crop cover; herbicide resistance; forage crops

\section{Introduction}

Despite decades of intensive herbicide use, lack of weed control is a serious problem in rice fields worldwide [1]. Flooding avoids the emergence of many species but others are perfectly adapted to inundation, the most difficult weeds in this crop being Echinochloa spp. and some Cyperaceae all over Europe [1,2], as well as in other parts of the world, e.g., in Arkansas and California in the USA [3,4], and in Asian countries such as Japan [5] and China [6]. Moreover, biotypes of several Echinochloa species have developed herbicide resistance, and currently 35 different herbicide-resistant populations have been reported worldwide for Echinochloa crus-galli alone in rice [7], the first confirmed case being in Greece in 1989 [8]. Concerning the other later-emerging species of this genus, resistance has been proved in two E. oryzoides populations in the USA and Turkey and in six populations of E. oryzicola (=E. phyllopogon) in USA, France, Greece and South Korea [7]. Moreover, in Spain, resistance of several Echinochloa species has been reported [9] and control with alternative herbicides is irregular [10].

Rice needs sufficiently high temperatures for at least 5 months [11] and is extremely dependent on abundant irrigation water. For this reason, heavy clay soils with deficient drainage are often selected for this crop to save water resources. In most rice growing areas of Spain farmers do not rotate with other crops because soils with bad infiltration rates 
or salinity problems, useful for rice, are not appropriate for other crops. This monocrop situation increases the existing weed control problems.

It is generally accepted that crop rotations contribute to weed control, breaking weed life cycles. However it is also reasonable to expect that generally several years should be necessary to achieve substantial seedbank and emergence reductions, taking into account that weed seeds often have a long survival rate. In non-irrigated system in a semiarid steppe, the best weed population reductions were achieved by rotating two different winter crops and two different summer crops [12]. Other long-term studies extend the optimal rotation up to six years, obtaining in that case high crop productivity and a long-term weed management with low herbicide use combining the diversified crop rotation with other cultural and herbicide methods [13].

Taking into account that $E$. crus-galli seeds are capable of surviving up to 17 years buried at a depth of $20 \mathrm{~cm}$ in a silty clay loam soil and up to 12 years in a fine sandy loam [14], it is foreseeable that an effective decline of this species will need a long-lasting strategy. Moreover, Gardarin et al. [15] found an annual mortality of 0.01 seeds $\times$ seeds $^{-1} \times$ year $^{-1}$, which represents a very slow seed decline in the soil.

As defined by Liebman and Gallandt [16], ecological and integrated weed management (IWM) requires from "many little hammers" insofar as different strategies are needed to efficiently control weeds. One possibility is to cultivate the soil by means of a false seedbed. E. crus-galli emerging later than the four-leaf stage of maize causes lower competition and grain loss than plants which established earlier [17]. In rice, E. crus-galli plants emerging 30 or 45 days after the crop also produced less viable seeds. Thus, any cultural weed management technique capable of delaying the emergence of the weed would probably contribute to reducing weed biomass and seed production [18]. Unfortunately, information on the IWM options is very scarce and solutions proposed in some countries such as e.g., combination of hand weeding and herbicide use (in Pakistan) are not viable in other countries with higher labor costs [19]. Other solutions are closely related to specific cultural singularities, such as the combination of rice and duck farming, which caused a notable reduction of E. crus-galli seeds in early-seeded rice in China [20].

In tropical regions, rice is rotated with wheat or peas but in temperate regions possible candidates are forage crops or sowing a summer crop instead of rice, e.g., maize or sunflower. However, the limitation of saline soils conditions the candidate crops.

Due to a severe drought in NE Spain in 2011-2012, some farmers interrupted the rice monocrop and decided to seed other crops, i.e., winter cereal (wheat, Triticum aestivum L. and barley, Hordeum vulgare L.) and forage crops (fescue, Festuca arundinacea Schreb., ryegrass, Lolium multiflorum Lam. and lucerne, Medicago sativa L.). The aims of this study were (1) to describe the weeds in the alternative crops after many years of rice monocrop, (2) to find out if the rotations might reduce the abundance and frequency of Echinochloa spp. in the short term.

\section{Materials and Methods}

In the rice growing area of Aragon (in Huesca and Zaragoza provinces, northeastern Spain), irrigation water for this crop comes from artificial reservoirs and is stored during winter to be used in the dry summer. After a drought in the winter of 2011-2012, many farmers decided to set aside the plots that year, as they were late for seeding winter crops and did not know until spring if they would have available water. However, some farmers decided to seed forage crops (fescue, ryegrass and lucerne) in March or September. Some farmers returned to rice in 2013 after abundant rainfall and water availability but others continued with the different crops installed during 2012. Rice-cultivated area in Aragon was 13,904 ha in 2011 and decreased to only 6761 ha in 2012 [21]. Taking advantage of this extraordinary situation in an area where normally rice is grown as a monoculture, plots were selected in Zaragoza province with the aid of a local advisor in 2014 (Figure 1). 


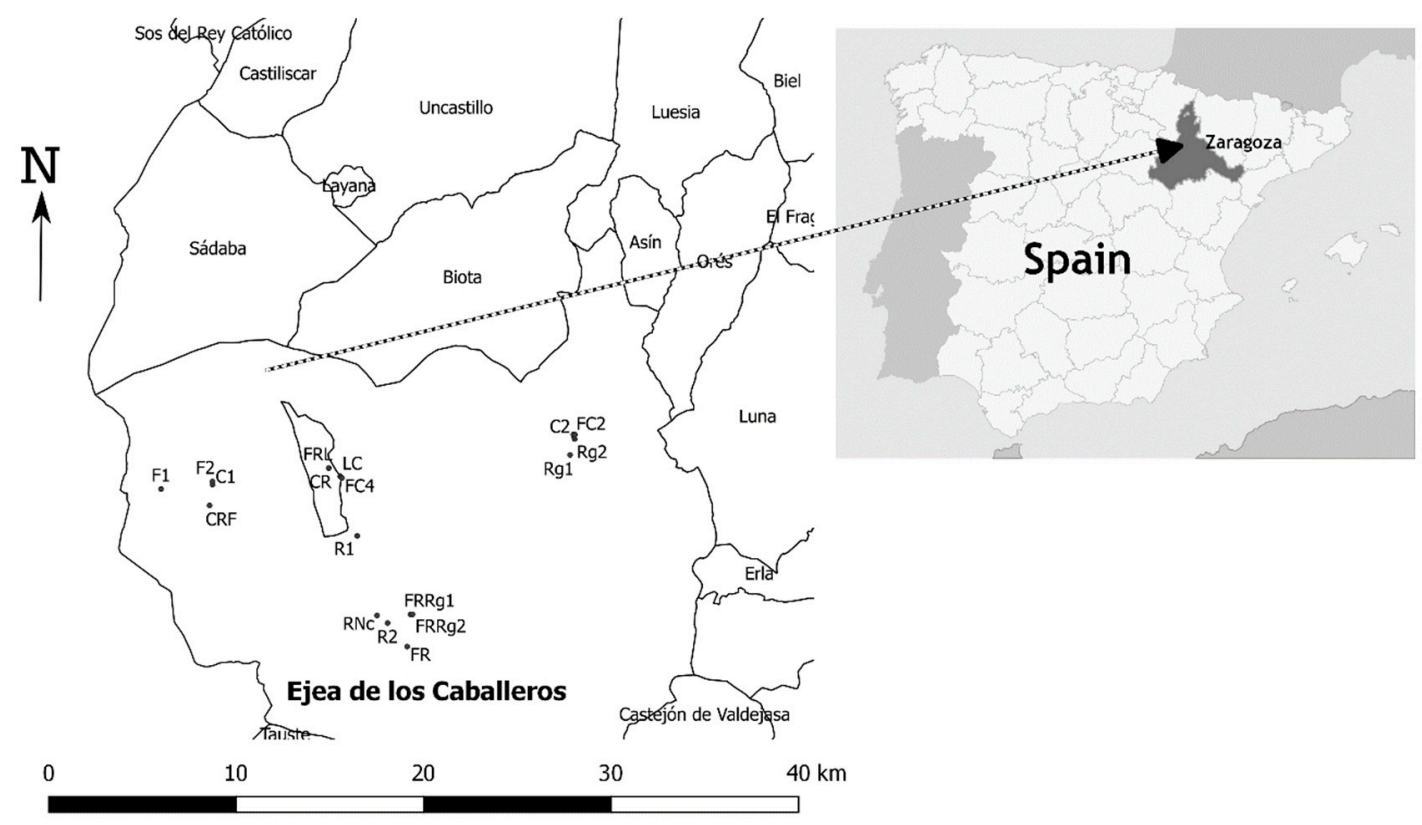

Figure 1. Map showing the position of the different surveyed fields.

The selected crops were fescue $(F)$, ryegrass $(R g)$, ryegrass + fescue $(R g+F)$, and winter cereal, i.e., barley or wheat (C), lucerne (L) and rice (R). A total of 20 fields that had been sown with rice for many years were surveyed in 2014, 2015 and 2016 (Table 1). Plots were selected in different locations to survey fields on several soil types; plots also belonged to several farmers, with the aim of including different agronomic management practices in order to obtain the broadest possible view. The intention was to survey at least two fields with the same crop sequences over several years, but some farmers decided to change the crop in 2015 or 2016. To address this situation other new fields were included in 2015 in an attempt to complete the scenarios (Table 1). The crops with the least replicates were lucerne, the mixture ryegrass + fescue and ryegrass; on the other hand, it was easier to find fescue fields in different positions of the crop sequences (Table 1).

According to the farmers, herbicides were only used in R fields and in one barley field (Table 2).

Table 1. Crops grown on the different surveyed plots between 2012 and 2016 in Aragon, Spain.

\begin{tabular}{cccccc}
\hline Plot Name & 2012 (Ns) & 2013 (Ns) & 2014 & 2015 & 2016 \\
\hline \multicolumn{2}{c}{ Plots with the same crop in 2014-2016 } & & Fescue \\
F1 (Fescue 1) & Rice & Nc & Fescue & Fescue & Fescue \\
F2 (Fescue 2) & Rice & Nc & Fescue & Fescue & Ryegrass \\
Rg1 (Ryegrass 1) & Rice & Ryegrass & Ryegrass & Ryegrass & Ryegrass \\
Rg2 (Ryegrass 2) & Nc & Ryegrass & Ryegrass & Ryegrass & Wheat \\
C1 (Cereal 1) & Rice & Nc & Barley & Barley & Wheat \\
C2 (Cereal 2) & Nc & Wheat & Wheat & Wheat & Rice \\
R1 (Rice 1) & Rice & Rice & Rice (Ns) & Rice & Rice \\
R2 (Rice 2) & Rice & Rice & Rice (Ns) & \\
\hline
\end{tabular}


Table 1. Cont.

\begin{tabular}{|c|c|c|c|c|c|}
\hline Plot Name & 2012 (Ns) & 2013 (Ns) & 2014 & 2015 & 2016 \\
\hline \multicolumn{6}{|c|}{ Plots with different crops in 2014-2016 } \\
\hline $\mathrm{CRg}+\mathrm{F}$ (Cereal-ryegrass+fescue) & Rice & Barley & Barley & Ryegrass and fescue & Ryegrass and fescue \\
\hline FC1 (Fescue-cereal 1) & $\mathrm{Nc}$ & Wheat & Fescue & Wheat & Wheat \\
\hline FC2 (Fescue-cereal 2) & Nc & Wheat & Fescue & Fescue & Wheat \\
\hline FC3 (Fescue-cereal 3) & $\mathrm{Nc}$ & Rice & Fescue & Fescue & Wheat \\
\hline FC4 (Fescue-cereal 4) & $\mathrm{Nc}$ & Rice & Fescue & Fescue & Wheat \\
\hline LC (Lucerne-cereal) & Nc & Rice & Lucerne & Lucerne & Wheat \\
\hline CR (Cereal-rice) & $\mathrm{Nc}$ & Rice & Wheat & Rice & Rice \\
\hline FRNcL (Fescue-rice-Nc-lucerne) & $\mathrm{Nc}$ & Fescue & Rice & $\mathrm{Nc}$ & Lucerne \\
\hline FR (Fescue-rice) & $\mathrm{Nc}$ & Fescue & Fescue (Ns) & Rice & Rice \\
\hline FRRg1 (Fescue-rice-ryegrass 1) & Rice & Fescue & Fescue (Ns) & Rice & Nc, ryegrass \\
\hline FRRg2 (Fescue-rice-ryegrass 2) & $\mathrm{Nc}$ & Fescue & Fescue (Ns) & Rice & Nc, ryegrass \\
\hline RNc (Rice-Nc) & Rice & Rice & Rice (Ns) & Rice & $\mathrm{Nc}$ \\
\hline
\end{tabular}

Ns: not surveyed; Nc: no crop.

Table 2. Herbicides used in the different surveyed fields between 2014 and 2016 in Aragon, Spain.

\begin{tabular}{|c|c|c|c|}
\hline Plot*/year & 2014 & 2015 & 2016 \\
\hline $\mathrm{C} 1$ & pinoxaden (barley) & - & - \\
\hline $\mathrm{R} 1$ & - & $\begin{array}{l}\text { Oxadiazon }+ \text { penoxsulam }+ \\
\text { azimsulfuron }\end{array}$ & $\begin{array}{l}\text { Oxadiazon }+ \text { penoxsulam }+ \\
\text { azimsulfuron }\end{array}$ \\
\hline $\mathrm{R} 2$ & - & $\begin{array}{l}\text { Oxadiazon }+ \text { penoxsulam }+ \\
\text { azimsulfuron }\end{array}$ & $\begin{array}{c}\text { Oxadiazon }+ \text { penoxsulam }+ \\
\text { azimsulfuron }\end{array}$ \\
\hline CR & - & Profoxidim + penoxsulam & profoxdim + penoxsulam \\
\hline FR & - & $\begin{array}{l}\text { Oxadiazon }+ \text { penoxsulam }+ \\
\text { bispyribac }\end{array}$ & penoxsulam \\
\hline FRRg1 & - & $\begin{array}{l}\text { Oxadiazon + cihalofop-p-butil + } \\
\text { penoxsulam + bispyribac }\end{array}$ & - \\
\hline FRRg1 & - & $\begin{array}{l}\text { Oxadiazon + cihalofop-p-butil + } \\
\text { penoxsulam + bispyribac }\end{array}$ & - \\
\hline RNc & $\begin{array}{c}\text { cihalofop-p-butil + } \\
\text { penoxsulam + bispyribac }\end{array}$ & $\begin{array}{c}\text { cihalofop-p-butil }+ \text { penoxsulam }+ \\
\text { bispyribac }\end{array}$ & - \\
\hline
\end{tabular}

* Abbreviations: see Table 1.

\subsection{Weed Survey}

Weeds growing in the fields were described in zigzag transects by three trained persons for at least $30 \mathrm{~min}$ in each field until no new species were found [22] in spring, summer and autumn 2014, 2015 and 2016. The abundance of all species found was recorded according to the visual CEB scale ([23]), which relates plant density with weed soil cover in the lower abundance categories, facilitating the estimation. The CEB scale ranges from 1 to 10 , which corresponds to categories of soil cover percentages of $<1 \%$ (rare plants), $1-7 \%$ $\left(<1\right.$ plant $\left.\mathrm{m}^{-2}\right), 7-15 \%$ (>1 plant $\left.\mathrm{m}^{-2}\right), 15-30 \%, 30-50 \%, 50-70 \%, 70-85 \%, 85-93 \%$, and 93-100\%. For data processing, an intermediate percentage value was assigned for each category, i.e., $0.2,4,11,22.5,40,60,77.5,89$ and $96.5 \%$, respectively. Species appearing only in the boundaries were not taken into account and those plants that could not be classified in the field were identified in the laboratory with the aid of local floras [24-26]. Percentage crop cover was also recorded at each sampling moment. Data on crop height were discarded because data interpretation was difficult due to the different mowing timings of the forage crops.

\subsection{Soil Analysis}

A mixed soil sample was taken in each field from three soil cores of $0-20 \mathrm{~cm}$ depth on 20 November 2019. The analysed parameters were texture, $\mathrm{pH}$, organic matter content, $\mathrm{P}$ (Olsen), K, electrical conductivity and preliminary salinity test (Table 3). In those soils 
where salinity exceeded $0.3 \mathrm{dS} \mathrm{m}^{-1}, \mathrm{Ca}, \mathrm{Mg}$ and $\mathrm{Na}$ were additionally analysed to calculate saturation percentage (Table 4). The analyses were conducted by the Agro-Environmental Laboratory of the Government of Aragon, following the UNE-EN ISO/IEC 17025 standard.

\subsection{Data Analysis}

Mean crop cover and mean weed cover were calculated for the different crops for each season and richness was calculated. Data was tested for normality and homoscedasticity and transformed following $\times{ }^{\wedge} 0.3$ when needed. ANOVA were performed and the Tukey mean separation test conducted for this data $(P<0.05)$ using the statistical $\mathrm{R}$ program, version 2.15.0 [27]. Linear regressions between crop soil cover and weed cover were conducted using Minitab version 13 (Minitab, LLC; State College, PA, USA).

Due to the large diversity in crop sequences, data referring to species richness and weed cover were displayed for each field and sampling moment individually to facilitate understanding of changes in time and to allow comparisons between different crop rotations.

Table 3. Soil analysis data of the 20 surveyed fields in Aragon, Spain. In bold, samples that were subjected to an additional salinity test due to salinity $\geq 0.4 \mathrm{dS} \mathrm{m}^{-1}$.

\begin{tabular}{|c|c|c|c|c|c|c|c|c|c|c|c|}
\hline Plot* & $\begin{array}{c}\text { Sand } \\
(\%)\end{array}$ & $\begin{array}{l}\text { Coarse } \\
\text { Loam } \\
(\%)\end{array}$ & $\begin{array}{c}\text { Fine } \\
\text { Loam } \\
(\%)\end{array}$ & $\begin{array}{c}\text { Clay } \\
(\%)\end{array}$ & Texture & $\mathrm{pH}$ & $\begin{array}{c}\text { Salinity } \\
* * \\
\left(\mathrm{dS} \mathrm{m} \mathrm{m}^{-1}\right)\end{array}$ & $\begin{array}{c}\text { Organic } \\
\text { Matter } \\
(\mathrm{g} / 100 \mathrm{~g})\end{array}$ & $\begin{array}{c}P \\
(\mathrm{mg} \\
\left.\mathrm{kg}^{-1}\right)\end{array}$ & $\begin{array}{c}\mathrm{K} \\
(\mathrm{mg} \\
\left.\mathrm{kg}^{-1}\right)\end{array}$ & $\begin{array}{r}\mathrm{Mg} \\
(\mathrm{mg} \\
\left.\mathrm{kg}^{-1}\right)\end{array}$ \\
\hline $\mathrm{F} 1$ & 10.43 & 6.42 & 43.03 & 40.12 & silty clay & 8.6 & 0.2 & 3.46 & 20 & 162 & 232 \\
\hline F2 & 4.69 & 11.37 & 59.92 & 24.02 & silt loam & 8.8 & 0.2 & 1.88 & 4 & 96 & 226 \\
\hline $\operatorname{Rg} 1$ & 22.68 & 11.49 & 35.81 & 30.02 & clay loam & 8.8 & 0.3 & 2.94 & 5 & 212 & 340 \\
\hline Rg2 & 8.73 & 8.93 & 47.82 & 34.52 & silty clay loam & 8.9 & 0.3 & 2.15 & 7 & 158 & 274 \\
\hline $\mathrm{C} 1$ & 5.19 & 8.48 & 55.29 & 31.04 & silty clay loam & 8.4 & 0.3 & 2.29 & 20 & 262 & 220 \\
\hline $\mathrm{C} 2$ & 11.98 & 10.5 & 44.16 & 33.36 & silty clay loam & 8.6 & 0.4 & 2.24 & 6 & 292 & 270 \\
\hline R1 & 20.06 & 7.39 & 37.82 & 34.73 & clay loam & 8.4 & 0.4 & 2.88 & 32 & 254 & 311 \\
\hline $\mathrm{R} 2$ & 4.23 & 4.79 & 44.76 & 46.27 & silty clay & 8.4 & 0.3 & 3.38 & 32 & 348 & 478 \\
\hline $\mathrm{CRgF}$ & 3.6 & 4.4 & 54.9 & 37.1 & silty clay loam & 8.5 & 0.6 & 2.59 & 6 & 236 & 401 \\
\hline FC1 & 10.7 & 8.33 & 45.79 & 35.18 & silty clay loam & 8.8 & 0.3 & 2.22 & 12 & 158 & 264 \\
\hline FC2 & 11.67 & 10.27 & 45.16 & 32.9 & silty clay loam & 8.4 & 0.9 & 2.01 & 8 & 182 & 259 \\
\hline FC3 & 32.74 & 8.16 & 29.6 & 29.5 & clay loam & 8.6 & 0.3 & 2.51 & 9 & 148 & 242 \\
\hline FC4 & 35.72 & 6.47 & 26.37 & 31.44 & clay loam & 8.5 & 0.3 & 2.95 & 19 & 268 & 192 \\
\hline LC & 32.94 & 5.77 & 30.75 & 30.54 & clay loam & 8.6 & 0.3 & 2.50 & 10 & 248 & 304 \\
\hline CR & 8.64 & 5.83 & 41.81 & 43.72 & silty clay & 8.6 & 0.3 & 3.53 & 39 & 328 & 354 \\
\hline FRNcL & 8.27 & 6.57 & 43.63 & 41.53 & silty clay & 8.5 & 0.3 & 3.73 & 14 & 256 & 354 \\
\hline FR & 4.01 & 2.1 & 36.87 & 57.02 & clay & 8.7 & 0.4 & 2.88 & 16 & 320 & 548 \\
\hline FRRg1 & 17.8 & 7.3 & 40.6 & 34.3 & silty clay loam & 9.0 & 0.3 & 1.86 & 11 & 158 & 394 \\
\hline FRRg2 & 36.5 & 6.87 & 27.18 & 29.35 & clay loam & 8.8 & 0.2 & 2.51 & 17 & 102 & 234 \\
\hline $\mathrm{RNc}$ & 9.49 & 15.38 & 46.25 & 28.88 & silty clay loam & 8.7 & 0.2 & 2.01 & 22 & 174 & 272 \\
\hline
\end{tabular}

${ }^{*}$ Abbreviations: see Table $1 .{ }^{* *} \mathrm{EC}$ test using the paste at a ratio of $1: 5\left(\mathrm{EC} 1: 5\right.$ at $\left.25^{\circ} \mathrm{C}\right)$.

Table 4. Additional soil analysis data for the fields that had higher salinity values.

\begin{tabular}{|c|c|c|c|c|c|}
\hline Plot * & Electrical Conductivity ${ }^{* *}\left(\mathrm{dS} \mathrm{m}^{-1}\right)$ & $\begin{array}{c}\text { Saturation } \\
(\%)\end{array}$ & $\begin{array}{c}\mathrm{Ca} \\
\left(\mathrm{meql}^{-1}\right)\end{array}$ & $\begin{array}{c}\mathrm{Mg} \\
\left(\mathrm{meql}^{-1}\right)\end{array}$ & $\begin{array}{c}\mathrm{Na} \\
\left(\mathrm{meql}^{-1}\right)\end{array}$ \\
\hline $\mathrm{C} 2$ & 2.27 & 54.75 & 10.21 & 3.18 & 9.79 \\
\hline R1 & 2.38 & 50.00 & 14.10 & 3.45 & 7.90 \\
\hline $\mathrm{CRgF}$ & 3.62 & 60.25 & 12.52 & 5.75 & 21.17 \\
\hline FC2 & 6.72 & 52.75 & 22.03 & 9.30 & 44.83 \\
\hline FR & 1.52 & 69.25 & 5.56 & 2.65 & 8.30 \\
\hline
\end{tabular}

* Abbreviations: see Table $1 .{ }^{* *}$ EC saturated paste at $25^{\circ} \mathrm{C}$. 


\section{Results}

\subsection{General Results}

In all, 83 species were identified during the survey; 35 were annual forbs, 20 biennial or perennial forbs, 16 annual Poaceae, 8 biennial or perennial Poaceae, 2 annual Cyperaceae and 2 were perennial Cyperaceae. In the rice fields, 18 species were found in total; 2 were annual forbs, 4 biennial or perennial forbs, 4 annual Poaceae, 4 biennial or perennial Poaceae, 2 annual Cyperaceae, and 2 were perennial Cyperaceae.

\subsection{Soil Samples}

All soils had a very basic $\mathrm{pH}$ (8.4-9.0) (Table 3), which can be limiting for absorption of $\mathrm{P}, \mathrm{Mn}$, or $\mathrm{Zn}$ and Fe. All soils had a high loam and a low sand content and textures corresponded to silty clay $(20 \%)$, clay loam $(30 \%)$, silty clay loam $(40 \%)$, silt loam $(5 \%)$, and clay $(5 \%)$. Mean organic content was normal for irrigated fields $(2.63 \pm 0.13)$. Soils had a high proportion of silt and in some cases of clay, which might impede crop establishment. Salinity and sodicity were high in five fields; however, only field FC2 would be considered saline, with electrical conductivity (CE) $>4 \mathrm{dS} \mathrm{m}^{-1}$, while fields CRF, C2 and R1 are classified as medium saline, with CE between 2 and $4 \mathrm{dS} \mathrm{m}^{-1}$ (Tables 3 and 4). Following the explanations of the soil laboratory responsible, only the salinity of FC2 could be excessive for certain crops' performance.

The phosphorus content of the soils was generally appropriate for their textures (considered as standard between 8 and $12 \mathrm{ppm}$ ), but low in some fields (F2, CRgF, Rg1, Rg2 and $\mathrm{C} 2$ ) and high in others (CR, R1, R2, RNc, C1, F1 and FC4), in these last plots probably due to excessive fertilization. $\mathrm{K}$ values were also appropriate for the soils (considered appropriate between 150 and $300 \mathrm{ppm}$ for the present textures) and too low only for fields F2, FC3 and FRRg2 (Table 3).

The main limitation of the surveyed fields was probably the basic $\mathrm{pH}$, which may cause lack of availability of some nutrients; the most inappropriate soil for agricultural purposes was the saline field FC2, which was moreover near to the sodicity threshold.

\subsection{Crop Cover}

Soil cover in spring was lowest for the newly established L fields and for the recently planted $\mathrm{R}$ compared to the rest of the crops (Table 5). In summer, soil cover was again lowest for $\mathrm{L}$, together with $\mathrm{Rg}$, and highest for F and R; in autumn, all crops showed similar soil cover. Concerning the performance of each crop from one season to another, Rg soil cover tended to be higher in spring but lower in summer and autumn, while F, L, and Rg + F maintained more homogeneous soil cover all year round. The mixture of Rg and F tended to cover the soil more than Rg alone and $\mathrm{R}$ logically performed better in summer and autumn than when recently sown in spring (Table 5).

In spring, weed cover was similar for all crops; but in summer and in autumn, weed cover was highest in L fields followed by Rg and R fields and was lowest in F (Table 5). As expected, Echinochloa spp. cover tended to be higher in autumn; in spring, some individuals were detected in $\mathrm{C}$ and $\mathrm{R}$ only. 


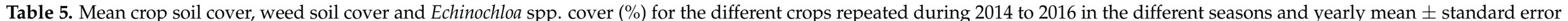
for the same values. Winter cereal was not surveyed after harvest in summer and autumn.

\begin{tabular}{|c|c|c|c|c|c|c|c|}
\hline Crop & Season & $\begin{array}{c}{ }^{1} \text { Mean Crop Soil } \\
\text { Cover }(\%)\end{array}$ & $\begin{array}{c}{ }^{1} \text { Mean Weed } \\
\text { Cover }(\%)\end{array}$ & $\begin{array}{c}\text { Mean Echinochloa spp. } \\
\text { Cover (\%) }\end{array}$ & $\begin{array}{c}{ }^{2} \text { Mean Crop Soil } \\
\text { Cover }(\%)\end{array}$ & $\begin{array}{c}\text { 2* Mean Weed Cover } \\
(\%)\end{array}$ & $\begin{array}{c}\text { Mean Echinochloa spp. } \\
\text { Cover (\%) }\end{array}$ \\
\hline Winter cereal & spring & $78 \pm 6.2 \mathrm{~A}$ & $16 \pm 5.4 \mathrm{~A}$ & $2 \pm 1.7$ & $77.9 \mathrm{a}$ & $8.1 \mathrm{~cd}$ & $2 \pm 1.7$ \\
\hline Fescue & $\begin{array}{l}\text { spring } \\
\text { summer } \\
\text { autumn }\end{array}$ & $\begin{array}{l}84 \text { a A } \\
82 \text { a M } \\
81 \text { a X }\end{array}$ & $\begin{array}{c}* 7.8 \times(17 \mathrm{~A}) \\
* 6.3 \times(11 \mathrm{O}) \\
* 2.7 \times(6 \mathrm{Z})\end{array}$ & $\begin{array}{c}0 \pm 0.0 \\
0.3 \pm 0.3 \\
1 \pm 1.1\end{array}$ & $81.8 \mathrm{a}$ & $5.4 \mathrm{~d}$ & $0.5 \pm 0.3$ \\
\hline Ryegrass & $\begin{array}{l}\text { spring } \\
\text { summer } \\
\text { autumn }\end{array}$ & $\begin{array}{c}75 \text { a } A B \\
46 \text { a } N \\
53 \text { a } X\end{array}$ & $\begin{array}{c}32.5 \times \mathrm{A} \\
50.8 \times \mathrm{MN} \\
57.8 \times \mathrm{XY}\end{array}$ & $\begin{array}{c}0 \pm 0.0 \\
0.1 \pm 0.0 \\
4 \pm 2.3\end{array}$ & $58.1 \mathrm{ab}$ & $42.5 \mathrm{ab}$ & $1.3 \pm 1.3$ \\
\hline Ryegrass+fescue & $\begin{array}{l}\text { spring } \\
\text { summer } \\
\text { autumn }\end{array}$ & $\begin{array}{c}60 \text { a } \mathrm{ABC} \\
67 \text { a } \mathrm{MN} \\
60 \mathrm{X}\end{array}$ & $\begin{array}{c}20.5 \times \mathrm{A} \\
13.9 \times \mathrm{NO} \\
12.7 \times \mathrm{YZ}\end{array}$ & $\begin{aligned} 0 & \pm 0.0 \\
1.3 & \pm 1.30 \\
4 & \pm 3.6\end{aligned}$ & $62.2 \mathrm{ab}$ & $13.6 \mathrm{bcd}$ & $2 \pm 1.2$ \\
\hline Lucerne & $\begin{array}{l}\text { spring } \\
\text { summer } \\
\text { autumn }\end{array}$ & $\begin{array}{c}37 \text { a BC } \\
40 \text { a } N \\
35 \text { a } X\end{array}$ & $\begin{array}{l}49.6 \times \mathrm{A} \\
60.3 \times \mathrm{M} \\
75.4 \times \mathrm{X}\end{array}$ & $\begin{array}{c}0 \pm 0.0 \\
15 \pm 12.7 \\
13 \pm 9.3\end{array}$ & $36.9 \mathrm{~b}$ & $55.7 \mathrm{a}$ & $9 \pm 5.2$ \\
\hline Rice & $\begin{array}{l}\text { spring } \\
\text { summer } \\
\text { autumn }\end{array}$ & $\begin{array}{l}36 \mathrm{bC} \\
76 \text { a M } \\
81 \text { a X }\end{array}$ & $\begin{array}{c}28.8 \times \mathrm{A} \\
26.8 \times \mathrm{MNO} \\
34.7 \times \mathrm{XYZ}\end{array}$ & $\begin{array}{c}12 \pm 5.5 \\
10 \pm 7.4 \\
21 \pm 10.2\end{array}$ & $63.0 \mathrm{ab}$ & $20.9 \mathrm{abc}$ & $15 \pm 4.6$ \\
\hline
\end{tabular}

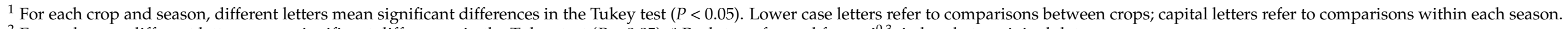

2 For each crop, different letters mean significant differences in the Tukey test $(P<0.05) .{ }^{*}$ Back-transformed from $\mathrm{x}^{\wedge 0,3}$, in brackets, original data. 
There was a significant relationship between crop and total weed cover $(P<0.001)$ (Figure 2) showing that crops with a higher soil cover competed better against weeds, leading to a lower weed cover (Figure 2).

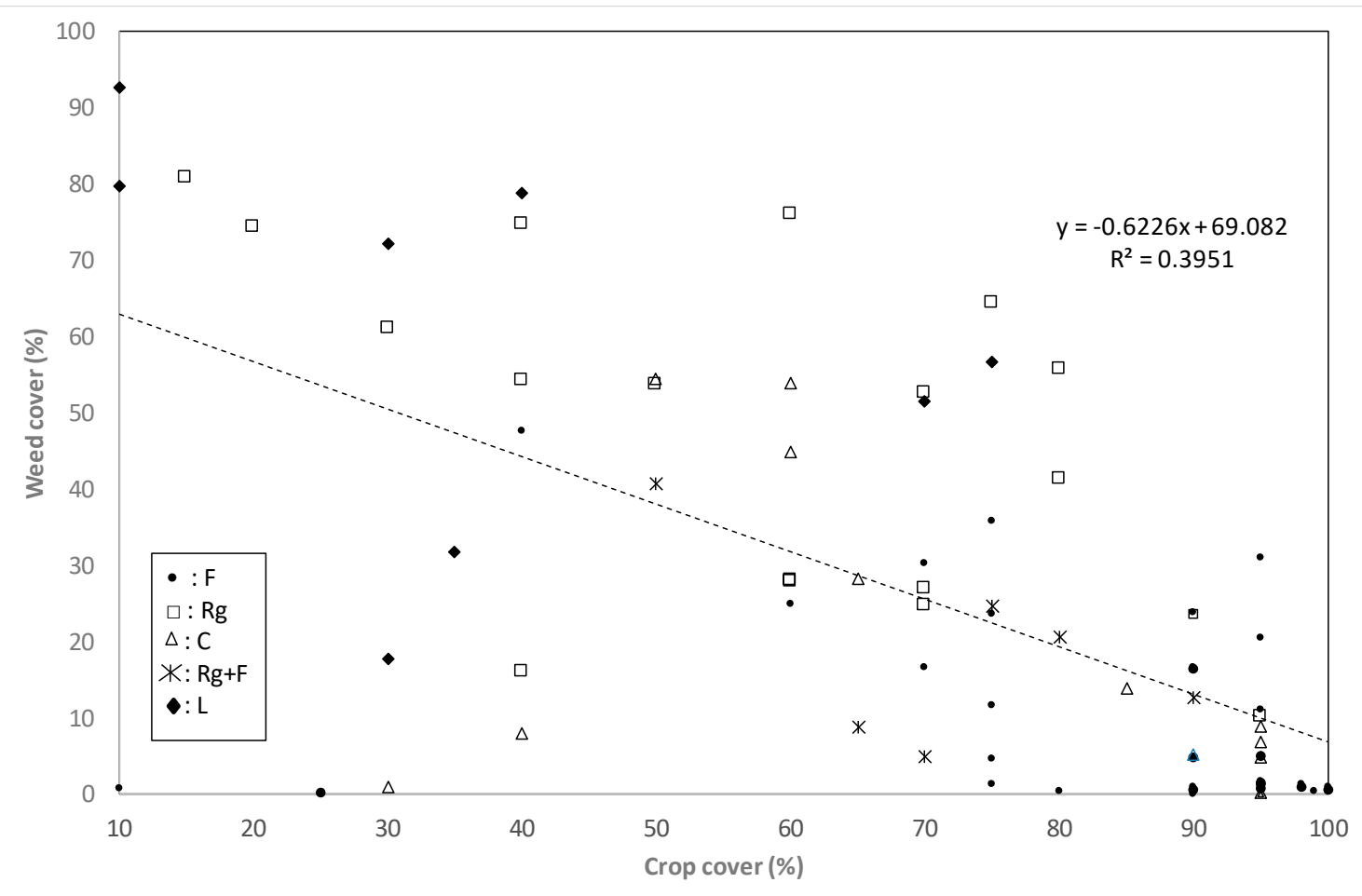

Figure 2. Regression between crop cover (\%) and weed cover (\%) in the surveyed plots of all crops and in all seasons pooled together.

\subsection{Species Richness and Weed Cover in Different Crop Situations}

\subsubsection{Winter Cereal Fields, Spring Evaluation}

Both species richness and mean weed cover were lower when $C$ was grown after $\mathrm{R}$ and NC (Figure 3) compared to growing $\mathrm{C}$ after other crops such as F or L (Figure 4). Values of both parameters tended to be higher in the fields where $C$ was grown after two years of $\mathrm{F}$ or $\mathrm{L}$ ( $37.6 \%$ weed cover, 12.7 richness) than when $\mathrm{F}$ was maintained only one year in the crop rotation (3.0\% weed cover, 7.0 species richness) (Figure 4 ).

Weed cover was high in cereal fields in three cases: in field C2 2016 in the C-C-C-C rotation (Figure 3), in plot FC3 2016 and in field FC4 2016 (both R-F-F-C) (Figure 4). In the first case the main weed was Sonchus oleraceus L., in field FC3 2016 the main weeds were Polypogon monspeliensis (L.) Desf. (22.5\%), Echinochloa oryzoides (Ard.) Fritsch and volunteer F. arundinacea (11\%), and in FC2 2016, E. oryzoides (22.5\%) and Rapistrum rugosum L. $(11 \%)$. The species S. oleraceus and P. monspeliensis are not usually problematic species in winter cereal in the area and a conventional post-emergence herbicide would probably have reduced the density. However, herbicide-resistant Rapistrum rugosum L. populations have been found in the area, suggesting that toleration of this species at high density should be avoided [28].

Echinochloa spp. plants were found in a few of these fields sampled in spring and summer (Table 6). However, the high abundance in FC3 and FC4 in 2016 is very probably due to a spring irrigation or rainfall that spring.

No weeds at all were found in $\mathrm{C} 1$ (Nc-C), where the herbicide pinoxaden was used. The two problem weeds in cereals in the area, i.e., A. sterilis and L. rigidum, exceeded $2 \%$ abundance in some fields, considered as the threshold for weed control according to the 
Integrated Pest Management guide published by the Spanish Ministry of Agriculture for cereal fields [29].



Figure 3. Weed species richness and total weed soil cover (\%) for the cereal crops in the spring surveys. The letters show the crops from 2013 until the sampling moment, the sampled crop being the last of the rotation (in larger letters). R: rice Nc: no crop, C: cereal.

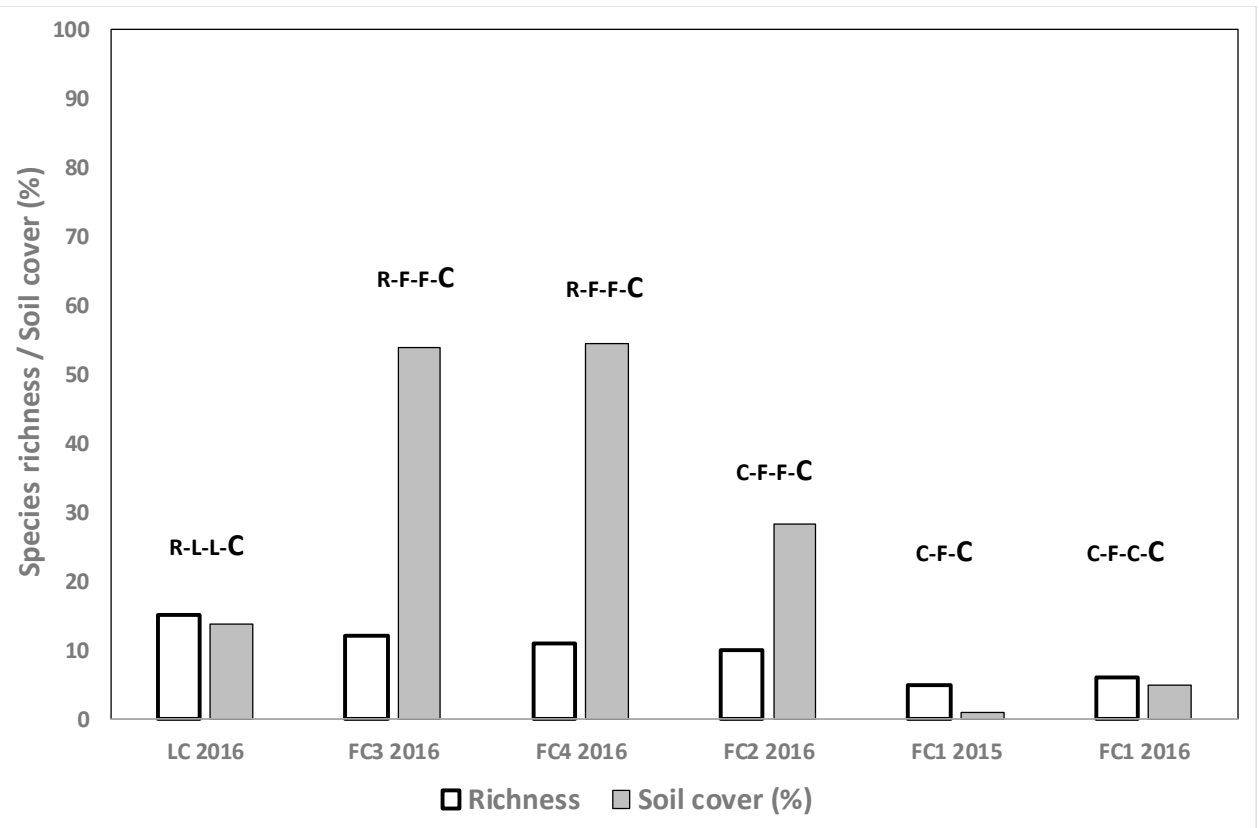

Figure 4. Weed species richness and total weed soil cover (\%) for the cereal crops grown in different crop rotation situations in the spring surveys. The letters show the crops from 2013 until the sampling moment, the sampled crop being the last of the rotation (in larger letters). R: rice, C: cereal, F: fescue, L: lucerne.

\subsubsection{Winter Cereal Fields, Summer and Autumn Evaluations}

Although $C$ is harvested in early summer, several fields were not ploughed until the end of autumn and weed soil cover was high in the summer evaluations. The most 
abundant weed species in summer were Abutilon theophrasti Medik. (22.5\% soil cover in field CR in 2014), P. monspeliensis and S. oleraceus (22.5\% soil cover each in field FC2 in 2016), Aster squamatus (Spreng.) Hieron, Medicago sp., Setaria pumila Poiret (Roemer \& Schultes) (22.5\% soil cover each in field LC in 2016) and A. squamatus (22.5\% soil cover in field FC3 in 2016). In autumn, the highest abundance was $40 \%$ soil cover by A. squamatus (field LC in 2016).

In a few cases, Echinochloa spp. were found in summer or autumn (Table 6) at $22.5 \%$ abundance in the highest case. The problem weed in rice Leptochloa fascicularis (Lam) Gray. was found only sporadically in field LC in summer and autumn $(0.2 \%)$, as was Cyperus difformis L. in field FC3 in autumn $2016(0.2 \%)$.

Table 6. Abundance of Echinochloa spp. (\%) in the winter cereal fields in summer and autumn and in their previous and subsequent crops. C: cereal, Rg: ryegrass, F: fescue, L: lucerne, R: rice.

\begin{tabular}{|c|c|c|c|c|c|c|}
\hline \multirow[b]{2}{*}{ Plot * } & \multicolumn{2}{|c|}{2014} & \multicolumn{2}{|c|}{2015} & \multicolumn{2}{|c|}{2016} \\
\hline & su & au & su & au & su & $\mathrm{au}$ \\
\hline \multirow{3}{*}{ CRF } & $C$ & $\mathrm{C}$ & $R g+F$ & $R g+F$ & $R g+F$ & $R g+F$ \\
\hline & 0.2 & 0 & 0 & 0 & 0 & 0 \\
\hline & $\mathrm{C}$ & C & $\mathbf{R}$ & $\mathbf{R}$ & $\mathbf{R}$ & $\mathbf{R}$ \\
\hline \multirow[t]{2}{*}{ CR } & 22.5 & 0.2 & 0 & 0 & 0 & 0 \\
\hline & $\mathrm{C}$ & $\mathrm{C}$ & $\mathrm{C}$ & $\mathrm{C}$ & $\mathrm{C}$ & $\mathrm{C}$ \\
\hline $\mathrm{C} 1$ & 0 & 0 & 0.2 & 0 & 0.2 & 0 \\
\hline \multirow[t]{2}{*}{$\mathrm{C} 2$} & 0 & 0 & 0.2 & 22.5 & 0 & 0 \\
\hline & L & L & L & L & $\mathrm{C}$ & $\mathrm{C}$ \\
\hline \multirow[t]{2}{*}{ LC } & 0 & 0 & 0 & 0 & 11 & 0.2 \\
\hline & F & $F$ & $\mathrm{C}$ & $\mathrm{C}$ & $\mathrm{C}$ & $\mathrm{C}$ \\
\hline FC1 & 0 & 0 & 4 & 4 & 0 & 0 \\
\hline FC3 & 0 & 0 & 0 & 0 & 0 & 0.2 \\
\hline
\end{tabular}

su: summer, au: autumn. ${ }^{*}$ Abbreviations: see Table 1.

\subsubsection{Fescue Fields after Rice}

In the first year growing $\mathrm{F}$ after $\mathrm{Nc}, \mathrm{C}$ or $\mathrm{R}$, species richness and weed cover tended to be higher in spring than in the summer and autumn assessments in all fields (Figure 5). However, data from the assessments in the second and third year of growing $F$ show that this trend occurred only in the first year and that many weeds disappeared from year to year due to mowing of the fescue (data not shown).

E. crus-galli was found at approximately $4 \%$ abundance in those $\mathrm{F}$ fields where $\mathrm{R}$ had been grown the previous year but not in the other fescue fields where either $\mathrm{C}$ or $\mathrm{Nc}$ had been grown after $\mathrm{R}$. This species was still detected at $0.2 \%$ in the autumn counts in fields FC1 and FC2 (data not shown).

Weed species richness and especially weed cover were very low in the second and in the third year of growing $\mathrm{F}$ in spring, summer and autumn (Figure 6); E. crus-galli was observed in the second year of growing $\mathrm{F}$ in only one field (FC2), at surprisingly high abundance (Figure 6). In fields F1 and F2, where the crop was maintained for a third year, weed species richness and weed cover remained low; E. crus-galli was present at $0.2 \%$ only in the second and third summer of F establishment in FC2 and no plants were detected in plot F1 at all. 


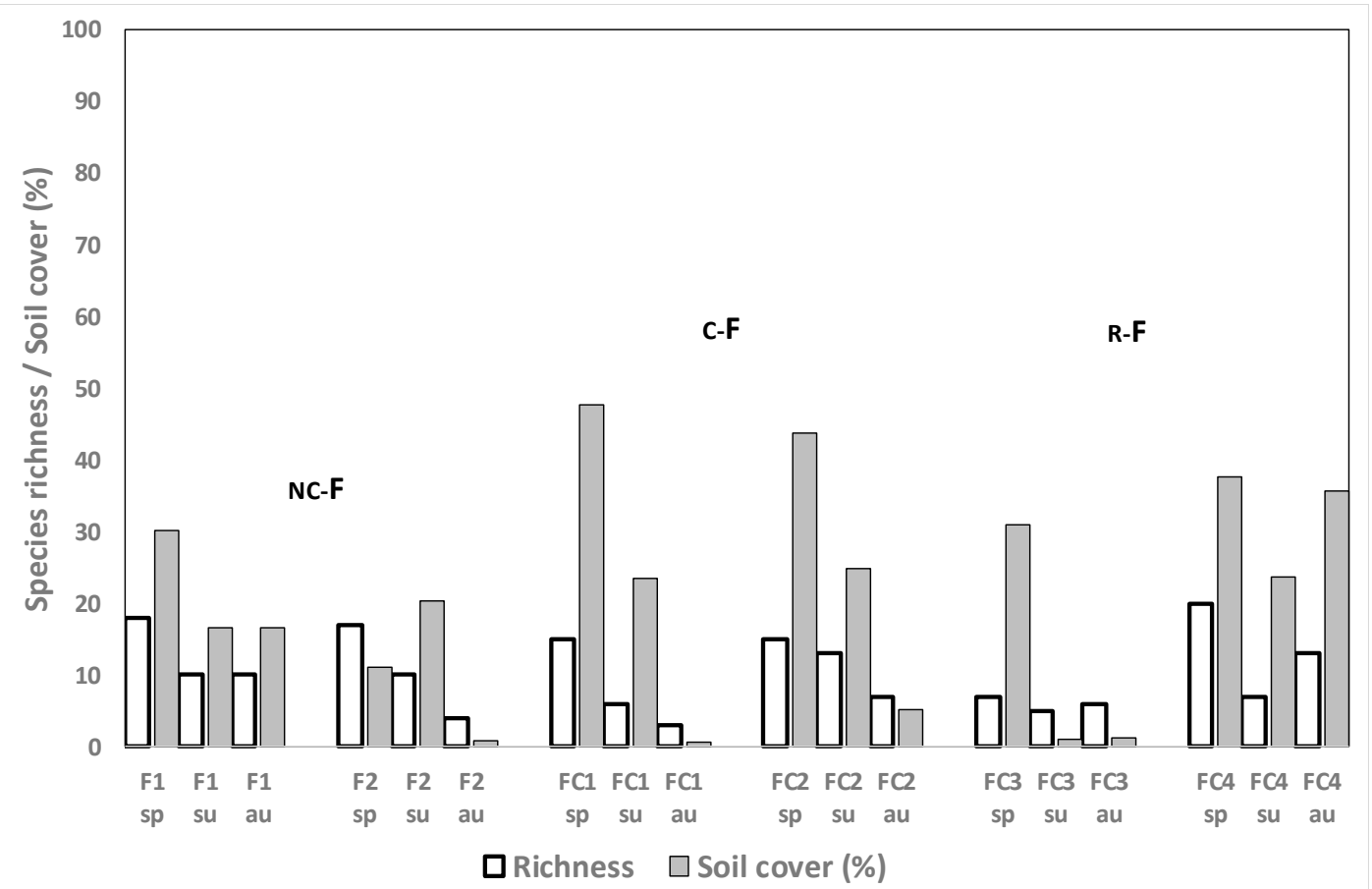

Figure 5. Weed species richness and total weed soil cover (\%) for the fescue fields in their first year of establishment in spring (sp), summer (sum) and autumn (au) 2014 in different crop rotation sequences. The letters show the crops from 2013 until the sampling moment, the sampled crop being the last of the rotation (in larger letters). R: rice, Nc: no crop, C: cereal, F: fescue.

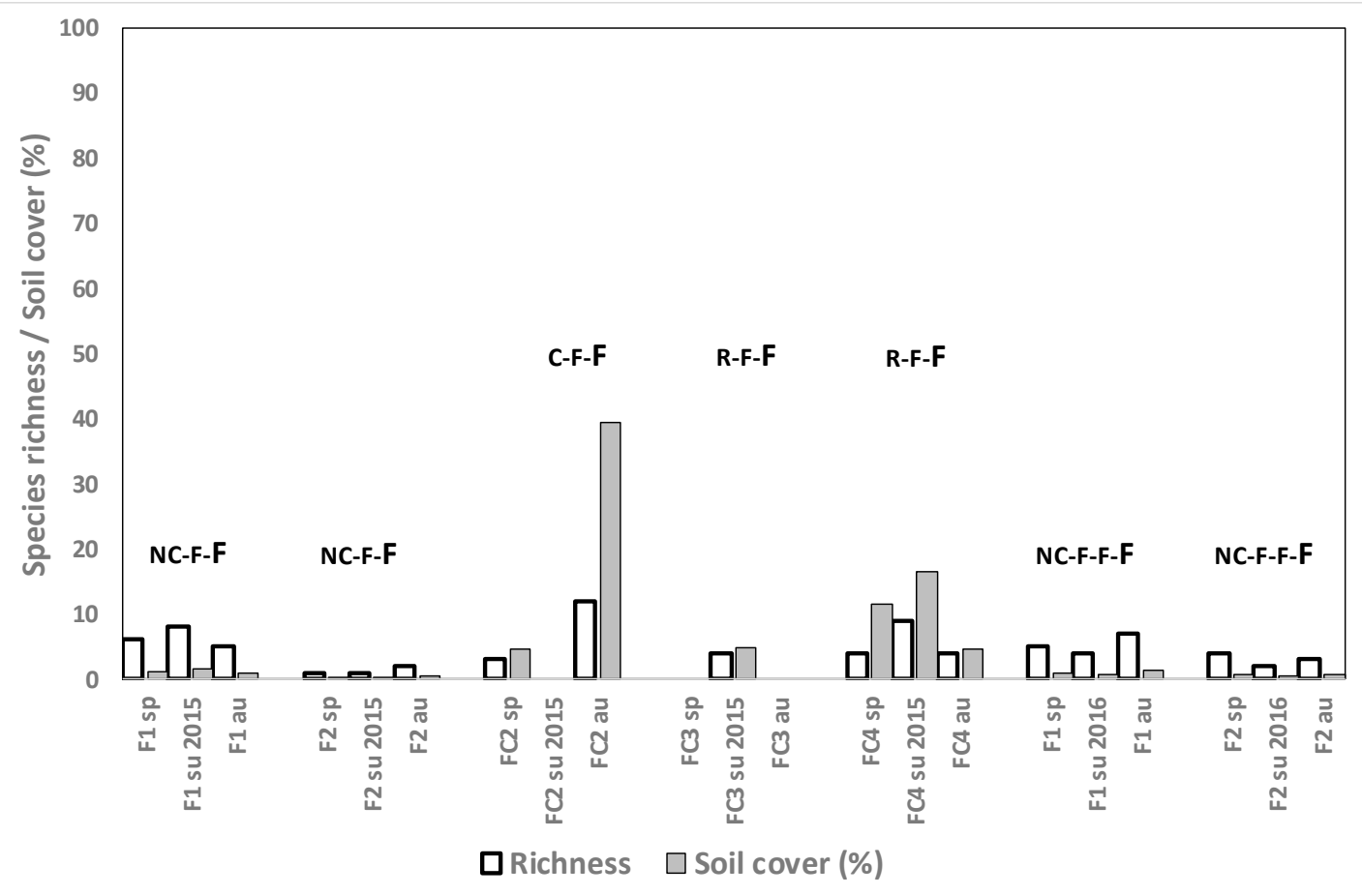

Figure 6. Weed species richness and total weed soil cover (\%) for the fescue fields in their second or third year of establishment (F1 and F2 in 2016) in spring (sp), summer (su) and autumn (au) in different crop rotation sequences. Individual species with $\geq 4 \%$ soil cover are listed below. The letters show the crops from 2013 until the sampling moment, the sampled crop being the last of the rotation (in larger letters). R: rice, Nc: no crop, F: fescue. 


\subsubsection{Forage Crops in Other Positions of the Rotation}

Weed species richness was higher in these fields than in the rest of the crop sequences presented until now: a mean of 11.3 for $\mathrm{Rg}, 7.8$ for $\mathrm{Rg}+\mathrm{F}$ and 12.9 for $\mathrm{L}$; but also weed cover was high: a mean of $47.0 \%$ for $\mathrm{Rg}, 18.8 \%$ for $\mathrm{Rg}+\mathrm{F}$ and $59.1 \%$ for $\mathrm{L}$ (Figure $7 \mathrm{a}, \mathrm{b}$ ). Abundance, however, tended to diminish in the third and fourth year of Rg installation (in both fields) and from the first to the second year of $\mathrm{Rg}+\mathrm{F}$ and of $\mathrm{L}$ (Figure 7a,b).
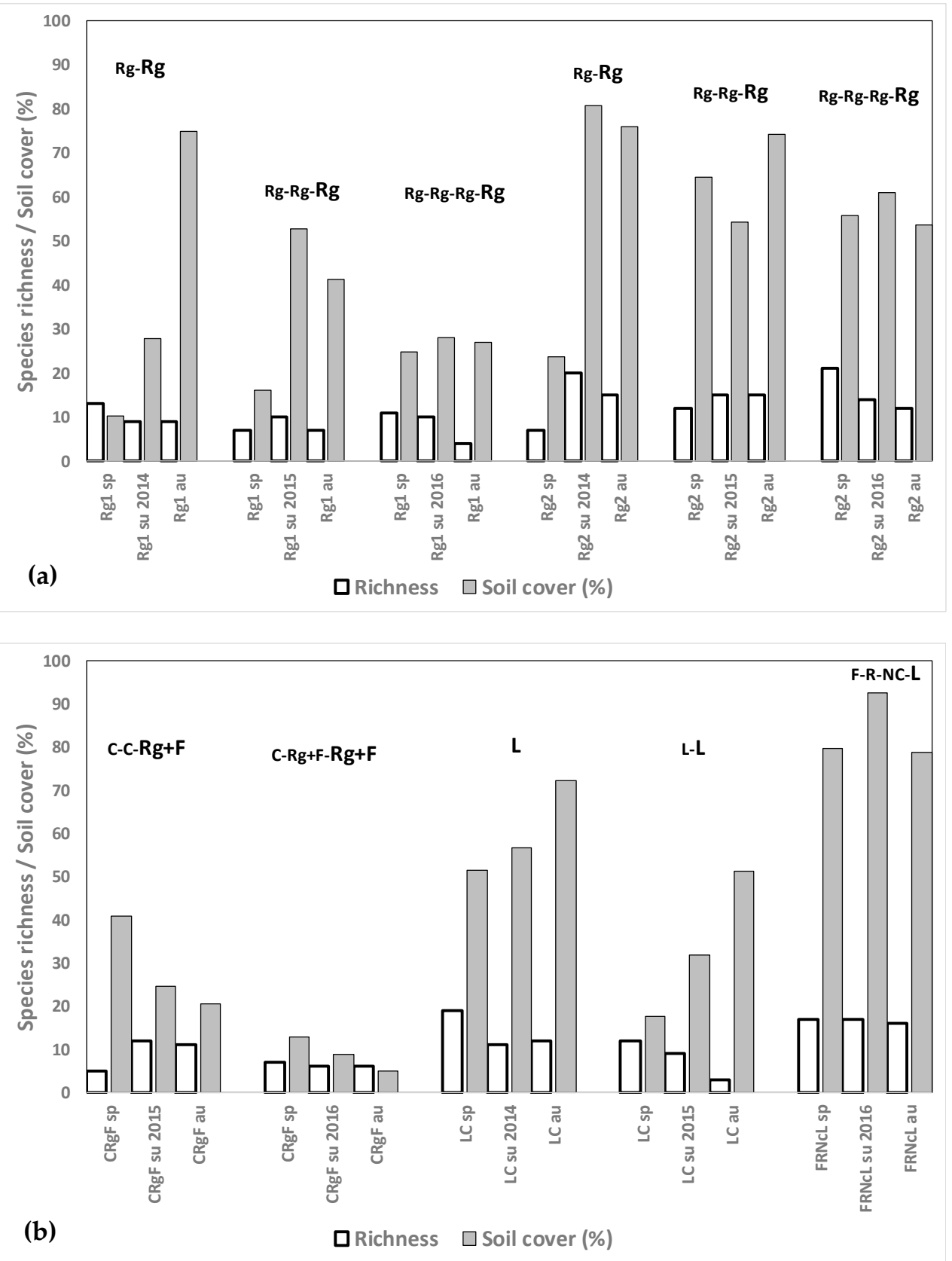

Figure 7. (a) Weed species richness and total weed soil cover (\%) for the ryegrass fields after growing rice in spring, summer and autumn 2014, 2015 and 2016 in different crop rotation sequences. The letters show the crops from 2013 until the sampling moment, the sampled crop being the last of the rotation (in larger letters). (b) Weed species richness and total weed soil cover (\%) for the fescue+ryegrass and lucerne fields after growing rice in spring, summer and autumn 2014, 2015 and 2016 in different crop rotation sequences. The letters show the crops from 2013 until the sampling moment, the sampled crop being the last of the rotation (in larger letters). C: cereal, R: rice, Rg: ryegrass, F: fescue, Nc: no crop, L: lucerne. 
Weed cover in the $\mathrm{Rg}$ and $\mathrm{L}$ fields was generally lower in spring than in summer and autumn. In fields Rg1, Rg2, LC, and FRNcL A. squamatus was the most dominant species, with abundance exceeding $22.5 \%$ at several sampling moments and even reaching $60 \%$ in field Rg2 in autumn 2015.

Despite the mowing of the crop, E. crus-galli was present in fields $\operatorname{Rg} 1$ and $\operatorname{Rg} 2$ in autumn 2015 and in summer 2016 (density of $0.2 \%$ ); but abundance in both fields in autumn 2014 had been much higher (11\%). In field LC up to $40 \%$ E. crus-galli infestations were observed during the first year of growing lucerne but they decreased to values of $4 \%$ in autumn 2016, possibly due to the better establishment of the crop in the second year. In field $\mathrm{CRgF}$, where $\mathrm{F}$ and $\mathrm{Rg}$ were grown mixed in the third year after $\mathrm{R}$, E. crus-galli abundance declined from $11 \%$ in the first autumn down to $4 \%$ in the second summer and $0.2 \%$ in the second autumn.

\subsubsection{Monocrop Rice Fields}

$\mathrm{R}$ fields grown in monocrop showed low weed species diversity but high abundance of several species (Figure 8) including C. difformis, red rice (O. sativa), and S. maritimus. The problem species E. crus-galli or E. oryzoides were present at all sampling moments in all three fields except for R1 in summer 2016. Echinochloa density was extremely high in field RNc (89\% soil cover in autumn 2015) despite herbicide applications, and resistance could be the cause of low efficacy. Moreover, the late-emerging species E. oryzoides invaded the field in autumn. In fields R1 and R2, the same herbicide mixtures were used in spring 2015 and 2016, showing quite effective results in both cases (data not shown). In field R2 population was relatively low (4\%) and did not increase with time; in field R1 population abundance decreased between spring and summer in both years and from 2015 to 2016 (data not shown).

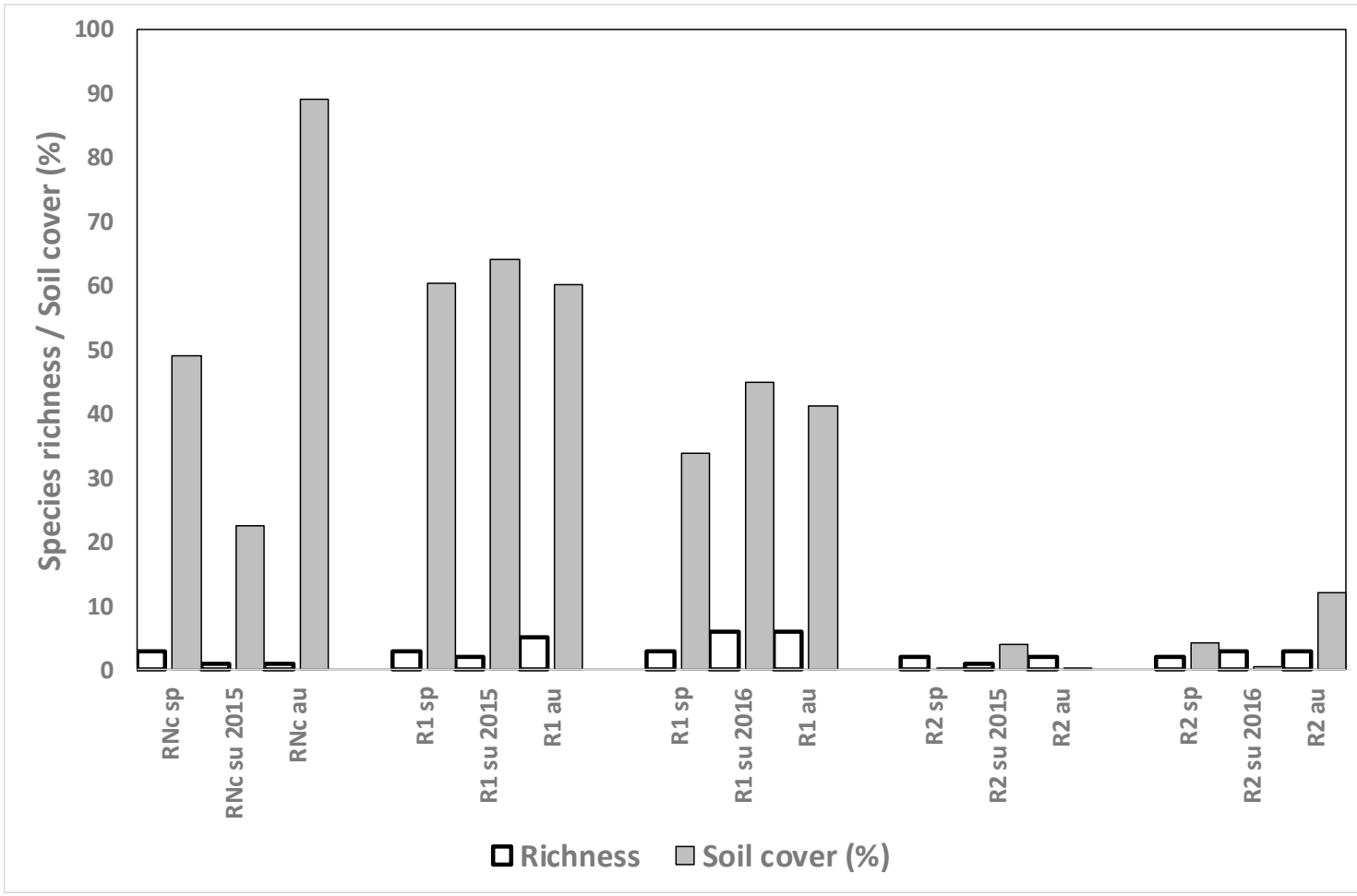

Figure 8. Weed species richness and total weed soil cover (\%) for the monocrop rice fields in spring (sp), summer (su) and autumn (au) 2015 and 2016. R: rice, Nc: no crop. 


\subsubsection{Rice after Growing Other Crops}

Weed species richness and abundance in the fields where $\mathrm{R}$ is grown after other crops tended to be similar to those found in R grown as a monocrop (Figures 8 and 9). In two fields (FRRg1 and CR in 2015), Echinochloa spp. were found at only $0.2 \%$ in summer and autumn and in fields FRRg2 and CR in 2016 abundance was slightly higher in autumn $(4 \%)$. These differences probably also depend on the initial population density in the $\mathrm{R}$ fields prior to the crop rotation. A serious infestation problem was found in plot FR, where herbicides seemed to control E. crus-galli in spring 2015 but a high population was found in spring 2016 which was not controlled at all, causing a soil cover of $97 \%$ in autumn, very probably because oxadiazon was not used in pre-emergence (Table 2, Figure 9). The most abundant species after Echinochloa was C. difformis, and in some plots L. fascicularis and wild rice.

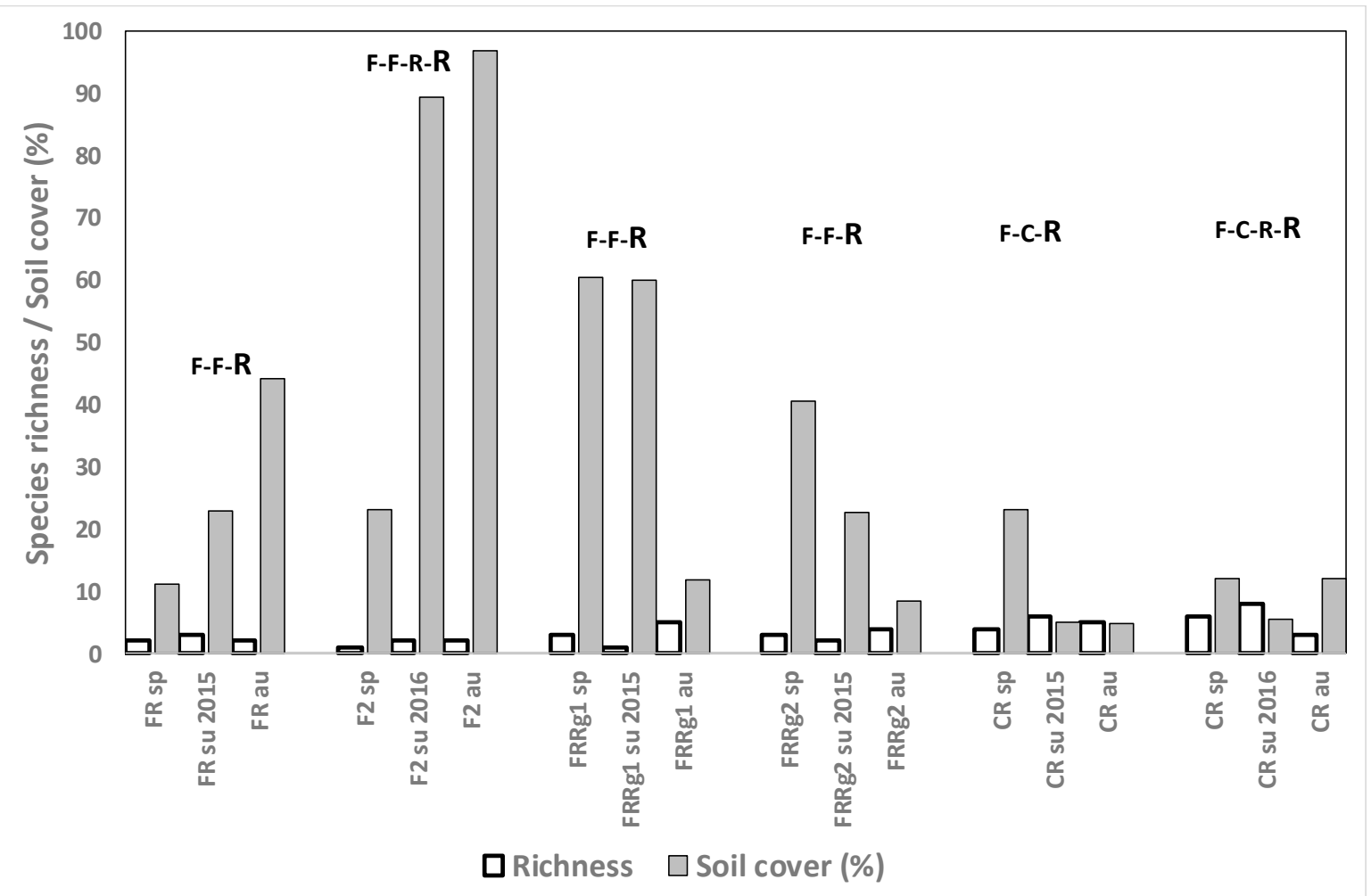

Figure 9. Species richness and total weed soil cover (\%) for the fields where rice is grown after other crops in spring, summer and autumn 2014, 2015 and 2016. The sampled crop is the last of the crop rotation.

\section{Discussion}

\subsection{General Results}

The overall weed species richness of 83 was logically greater than in specific assessments of rice fields, such as e.g., the 31 species found in 50 rice fields in Portugal [30] or the 66 weed species in 481 rice fields in a study conducted in Iran [31], because not only rice fields were surveyed in the present work. However, the 18 species found in 8 rice fields included the typical expected species of this crop and some others such as Polygonum aviculare L., Lolium perenne L., Paspalum distichum L., Medicago sp., Plantago coronopus L., P. majus and Rumex spp. that probably appeared thanks to the rotations. When considering all the crops, $66 \%$ of the species were forbs, and when focusing on the rice fields, $67 \%$ were Poaceae and Cyperaceae. 


\subsection{Crop and Weed Cover}

Soils had been cultivated in wet conditions for many years under flooded rice in all plots, so very probably the physical properties of the soils were responsible for the bad performance of $\mathrm{L}$, and the mediocre establishment of $\mathrm{Rg}$; barley is generally tolerant to salinity and $\mathrm{Rg}$ and $\mathrm{F}$ have medium tolerance to salt [32] and to compact soils.

Crops covering the soil appropriately led to lower weed infestations (Figure 2). However, data for the rice fields was less coherent because other factors, such as herbicide use also determine the presence of weeds. Although it is known that Echinochloa spp. are susceptible to crop competition [18], no relationship between the cover of species of this genus and the crops was found (data not shown), probably due to the irregular occurrence of this weed.

\subsection{Winter Cereal Fields}

In the spring evaluations species richness tended to be higher in the sampled $C$ fields than in other surveys conducted in the area, with a mean of 6.1 species (Figure 3), versus the mean richness of 2.84 in the nearby also irrigated Hoya de Huesca area [22]. Including forage crops such as F or L increased both species richness and weed cover, which is consistent with the findings of Yuan [33].

The Integrated Pest Management guides published by the Spanish Ministry of Agriculture for cereal and rice fields consider $2 \%$ soil cover as a threshold in a cereal or rice field to take a control method decision $[28,29]$. Following this criterion, S. oleraceus in fields $\mathrm{C} 1$ and $\mathrm{C} 2$ and A. clavatus, Rumex sp., Hordeum murinum L., Beta maritima L., Avena sterilis L. and Lolium rigidum Gaud. in other fields were the species surpassing this threshold and control methods should be applied. However, out of this list, only A. sterilis and L. rigidum can be considered serious weeds in winter cereal fields in the area [22,34]. It has been shown that S. asper [35,36], Rumex sp. [37], B. maritima [34] and H. murinum [38] are tolerant to salinity, which explains their ability to perform satisfactorily in the surveyed fields.

In the summer and autumn evaluations, the high abundance of A. squamatus in some fields was striking but is probably due to the good adaptation of this species to mowing and thus to growing in forage crops, being tolerant to salinity and growing as an opportunist on bare ground produced by overgrazing or salinization [39]. Moreover, this species is air-transported, so its origin might be from nearby forage crops, although this species has been found in rice fields $[39,40]$. On the other hand, the high abundance of $A$. theophrast $i$ in one plot is probably a consequence of having cultivated maize in that field in 2008-2010 (data from the official service) because the seedbank of this species is known to be very persistent [41]. P. monspeliensis is considered a typical weed in rice fields [1], as well as in other areas of Spain, where this species has been found in more than $50 \%$ of the surveyed rice plots [42]. The abundance of all these species is thus expectable in these winter cereals.

Moreover the abundance of S. olearceus is in accordance with observations of other scientists, as Lewin [43] found this species on the British Isles on many different substrates, including saline soils, but never on acid peat. The description in [35] in Canada is also in accordance with what has been found in the surveyed fields, claiming that this species primarily occurs on relatively moist soils, rich in sodium, phosphorus, potassium and calcium. Moreover Rumex spp. are stated to be tolerant to salinity [36].

The presence of other typical rice weed species that require a certain amount of moisture in the cereal stubble fields such as E. crus-galli or E. oryzoides in summer and autumn can only be due to precipitation, because these fields were not irrigated after harvest in late May or early June. Concerning E. crus-galli it is worth highlighting that this weed was found in spring, summer and autumn in different cereal fields even after growing $\mathrm{F}$, L or C for several years. The most outstanding cases were fields where $\mathrm{R}$ had not been grown for three or four years and Echinochloa plants were still present. These plants should be carefully controlled in the stubble to avoid new seed rain. These observations are coherent with the knowledge of persistence of this species in the soil, which has been found 
alive in the soil at $9-20 \%$ and $2-3 \%$ after 6 and 12 years of burial respectively, depending on the soil (but even longer at a lower percentage) [14].

Recommended cultural methods to be combined in an IWM strategy are thus: (1) to seed early-harvested cereals to avoid new seed rain of this summer-emerging species because $E$. crus-galli is known to be quite plastic in relation to its seed ripening moment [44]. Additionally, (2) ploughing of the cereal stubble should occur in summer after emergence of the rice weeds, preventing these species from finishing their cycle and enriching the soil seedbank with new seeds.

Other typical rice weeds were found less frequently in the cereal stubble, probably due to the fact that some of them like, such as Scirpus spp. and Cyperus spp., need water at a much more constant level than Echinochloa spp. and that occasional spring irrigation and summer rainfall was not enough to assure their development. In fact, E. crus-galli grows also in fruit orchards of the region as well as in maize fields, demonstrating that it is also well adapted to non-continuous high water levels [45]. In contrast, few L. fascicularis plants were found despite the fact that this species is specialized in growing in the borders of rice fields with high moisture availability but not under continuous high water levels [46]; [47]. Probably summer storms were not plentiful enough for its settlement.

\subsection{Fescue, Ryegrass and Lucerne Fields}

Despite the high salinity of FC2, F cover had a mean of $75 \%$, which is slightly lower than the mean of all $\mathrm{F}$ fields but still acceptable, confirming the saline tolerance of this crop.

The reason why weed species richness and weed cover tended to be higher in spring than in summer and autumn in F in its first year could be that in the spring counts, autumngerminating weeds were still visible before maturity and early spring-germinating species were already growing. However, abundance decreased from year to year when the crop became better established.

No official weed threshold limits are available for forage crops in the Spanish Integrated Pest Management regulations but private companies establish the following quality classes depending on the visual weed content of the forage: supreme quality: $0 \%$ weeds; premium quality: up to $3 \%$ weeds; first class quality: $3-8 \%$ weeds; second class quality: $8-25 \%$ weeds; ordinary or third class quality: more than $25 \%$ weeds [48]. Taking into account these limits, most of the $\mathrm{F}$ mowings of the surveyed fields in the first year after growing rice would correspond to second class quality, but achieving better quality classes in the second and third years (Figures 5 and 6 ). In fact, weed cover decreased in all surveyed $F$ fields in time. A. squamatus, P. monspeliensis and L. multiflorum were the most abundant species in these first mowings. L. multiflorum was very probably sown mixed with the forage crop. P. monspeliensis and A. squamatus come from the rice fields and, as explained previously, are well adapted to mowing and to saline soils [39]. Additionally, this species grows on overgrazed areas and indeed a sheep farm was next to fields $\operatorname{Rg} 1$ and $\operatorname{Rg} 2$ [39].

Unfortunately, in several fields small-size individuals of Echinochloa spp. were observed, adapted perfectly to the mowing and in some cases even generating seeds from very small plants. In contrast with the positive results in F, weed cover remained quite high for all three years in the Rg and in the L fields (Figure 7). These crops are probably less tolerant to salt or to heavy soil textures than F, thus allowing more weeds to grow. Nevertheless, few fields with these crops were available so further surveys with Rg and L would be desirable. Concerning Echinochloa spp., no plants were detected at some sampling moments in $\mathrm{F}$ and $\mathrm{L}$ fields but maximum abundance occurred in the first year of L establishment (field LC), reaching 40\% in summer 2014 and decreasing afterwards. However, in the two fields that maintained fescue for a third year, no Echinochloa plants were detected at all in the third year any more, suggesting that this crop might be able to reduce the abundance of this problem weed. Moreover, the results of the mixed forage crops of $\mathrm{Rg}$ and F showed promising crop cover and weed control data, even though field CRgF was one of the most saline soils (Table 3 ). This suggests that although there was only one available field, mixing 
two forage species such as $\mathrm{Rg}$ and $\mathrm{F}$ might be a good technique to assure better competition in fields that lack a good structure after many years of flooding.

Therefore, the third recommendation for Echinochloa spp. control in an IWM program is (3) to guarantee a high crop density of the mowed forage crops, using the correct seed rates and also by mixing different crops to assure a good crop soil cover.

\subsection{Monocrop Rice Fields}

All of the surveyed $R$ fields hosted the highest weed abundance and frequency values of the survey, confirming the big weed problem in rice crops [2]. E. crus-galli was found at more than $60 \%$ of the sampling moments in fields R1 and R2 E. oryzoides was found in RNc in 2015, and C. difformis was found at all the survey moments in at least one of the fields (data not shown). The Integrated Pest Management guide published by the Spanish Ministry of Agriculture for rice fields considers $2 \%$ soil cover as a threshold in a rice field for a control decision [49]. According to Reddy et al. [50], Echinochloa spp. start to compete with crops as early as the three-leaf stage and allelopathic effects are expected [51] that justify these thresholds. From this point of view, five typical rice weed species exceeded this threshold in one field and two species did so in the other (data not shown).

In several cases, E. crus-galli was abundant in the spring assessments and E. oryzoides was abundant in autumn. A possible reason might be resistance; but it also happens that the first species emerges earlier in the season and is, on occasion, efficiently controlled with herbicides whereas the second species finishes the cycle later (according to the literature, it is the last of the four Echinochloa species described in the area [24]) and is often not treated as it emerges after the treatments. Concerning herbicide use, the observations confirm that oxadiazon used in pre-emergence reduces Echinochloa spp. densities drastically, as found in other studies [10].

The following recommendation for IWM arises from these results: (4) it is important to take into account that several Echinochloa species emerge in rice fields and that some species germinate later than others, so more than one intervention might be necessary. However, as oxadiazon use in rice is no longer allowed in pre-emergence in rice since 2019, it cannot be recommended despite its positive effect in reducing early weed emergence.

\subsection{Rice after Growing Other Crops}

Although Echinochloa abundance was reasonably low in several rice fields after growing fescue or cereal, the results for field FR in the second year of $R$ after growing $F$ demonstrate that constant and efficient control methods need to be applied to avoid re-infestations when growing rice again some years afterwards. This result is again coherent with the high seed survival reported for Echinochloa species [14]. These observations suggest the last recommendation for IWC of Echinochloa spp.: (6) control methods need to be performed for more than 10 years to guarantee a depletion of the soil seedbank due to the long-lasting survival of the seeds in the soil.

\section{Conclusions}

The main conclusion of this work is that crop rotation alone is not sufficient to control Echinochloa spp. but needs to come along with detailed observation of the species performance, eliminating the plants before new seed shed. The staggered germination of the different Echinochloa species in rice fields forces the use of herbicides several times. In winter cereal, crops should be harvested early and stubble turned into the soil to prevent Echinochloa plants from finishing their cycle in summer. A high crop density needs to be achieved in the different forage crops surveyed in this work to assure that they compete efficiently with the weeds. Moreover, Echinochloa spp. have demonstrated their adaptation capacity to periodical mowing. Therefore a substantial reduction of the seedbank of both herbicide susceptible and resistant populations will only be possible if new seed shed is impeded efficiently for several years. 
Author Contributions: Conceptualization, G.P. and A.C.; methodology, G.P., A.C. and A.I.M.; software, A.C. and G.P.; formal analysis, A.C.; investigation, G.P., A.C., A.I.M. and J.A.; data curation, G.P. and AC.; writing-original draft preparation, A.C.; writing-review and editing, G.P., A.C., A.I.M. and J.A.; supervision, G.P. and A.C. All authors have read and agreed to the published version of the manuscript.

Funding: This research was funded by Ministerio de Economía y Competitividad. INIA RTA 2017-00098-00-00.

Acknowledgments: Thanks to S. Hernández for her help in selecting plots. Thanks to J. Betrán for his collaboration with the soil analyses and their interpretation.

Conflicts of Interest: The authors declare no conflict of interest.

\section{References}

1. Kraehmer, H.; Jabran, K.; Mennan, H.; Chauhan, B.S. Global distribution of rice weeds-A review. Crop Prot. 2016, 80, 73-86. [CrossRef]

2. Kraehmer, H.; Thomas, C.; Vidotto, F. Rice production in Europe. In Rice Production Worldwide; Springer International Publishing: Cham, Switzerland, 2017. [CrossRef]

3. Bagavathiannan, M.V.; Norsworthy, J.K.; Smith, K.L.; Burgos, N. Seedbank size and emergence pattern of barnyardgrass (Echinochloa crus-galli) in Arkansas. Weed Sci. 2011, 59, 359-365. [CrossRef]

4. Ruiz-Santaella, J.P.; Fisher, A.J.; De Prado, R. Alternative control of two biotypes of Echinochloa phyllopogon susceptible and resistant to fenoxaprop-ethyl. Commun. Agric. Appl. Biol. Sci. 2003, 68, 403-407.

5. Lin, D.; Tsuzuki, E.; Dong, Y.; Terao, H.; Xuan, T.D. Potential biological control of weeds in rice fields by allelopathy of dwarf lilyturf plants. BioControl 2004, 49, 187-196. [CrossRef]

6. Wang, X.L.; Zhang, Z.Y.; Xu, X.M.; Li, G. The density of barnyard grass affects photosynthesis and physiological characteristics of rice. Photosynthetica 2019, 57, 705-711. [CrossRef]

7. Heap, I. International Survey of Herbicide Resistant Weeds. Available online: http://www.weedscience.org/Summary/Species. aspx (accessed on 30 May 2019).

8. Giannopolitis, C.N.; Vassiliou, G. Propanil tolerance in Echinochloa crus-galli (1.) Beauv. Trop. Pest Manag. 1989, 35, 6-7. [CrossRef]

9. Romano, Y.; Mendoza, F.; Palmerín, J.A.; Quiles, J.; Amaro, I.; Osuna, M.D. Distribución de poblaciones resistentes de Echinochloa spp. a herbicidas inhibidores de la ALS y ACCasa en Extremadura. In Proceedings of the XVI Congreso de la Sociedad Española de Malherbología, Pamplona, Spain, 25-27 October 2017; Royuela, M., Zabalza, A., Eds.; Universidad Pública de Navarra: Navarra, Spain, 2017; pp. 269-271.

10. Pardo, G.; Marí, A.; Fernández-Cavada, S.; García-Floria, C.; Hernández, S.; Zaragoza, C.; Cirujeda, A. Alternatives to penoxsulam to control Echinochloa spp. and cyperaceous weeds in rice crop in NE Spain. ITEA Inf. Tec. Econ. Agrar. 2015, 111, 295-309. [CrossRef]

11. Farrell, T.C.; Fox, K.M.; Williams, R.L.; Fukai, S.; Lewin, L.G. Minimising cold damage during reproductive development among temperate rice genotypes. II. Genotypic variation and flowering traits related to cold tolerance screening. Aust. J. Agric. Res. 2006, 57, 98-100. [CrossRef]

12. Anderson, R.L. Managing weeds with a dualistic approach of prevention and control. A review. Agron. Sustain. Dev. 2007, 27, 13-18. [CrossRef]

13. Adeux, G.; Munier-Jolain, N.; Meunier, D.; Farcy, P.; Carlesi, S.; Barberi, P.; Cordeau, S. Diversified grain-based cropping systems provide long-term weed control while limiting herbicide use and yield losses. Agron. Sustain. Dev. 2019, 39, 42. [CrossRef]

14. Burnside, O.C.; Wilson, R.G.; Weisberg, S.; Hubbard, K.G. Seed longevity of 41 weed species buried 17 years in eastern and western Nebraska. Weed Sci. 1996, 44, 74-86. [CrossRef]

15. Gardarin, A.; Dür, C.; Mannino, M.R.; Busset, H.; Colbach, N. Seed mortality in the soil is related to seed coat thickness. Seed Sci. Res. 2010, 20, 243-256. [CrossRef]

16. Liebman, M.; Gallandt, E.R. Many Little Hammers: Ecological Management of Crop-Weed Interactions. In Ecology in Agriculture; Liebman, E.M., Gallandt, E.R., Eds.; Academic Press: Cambridge, MA, USA, 1997; pp. 291-343. [CrossRef]

17. Bosnic, A.C.; Swanton, C.J. Influence of barnyardgrass (Echinochloa crus-galli) time of emergence and density on corn (Zea mays). Weed Sci. 1997, 45, 276-282. [CrossRef]

18. Awan, T.H.; Chauhan, B.S. Effect of emergence time, inter- and intra-specific competition on growth and fecundity of Echinochloa crus-galli in dry-seeded rice. Crop Prot. 2016, 87, 98-107. [CrossRef]

19. Awan, T.H.; Saleem, M.U.; Hussain, S.; Ahmed, S.; Ali, H.H. Integrated weeds management in dry-seeded basmati rice. J. Anim. Plant Sci. 2019, 29, 1299-1307.

20. Wei, H.; Bai, W.; Zhang, J.; Chen, R.; Xiang, H.; Quan, G. Integrated rice-duck farming decreases soil seed bank and weed density in a paddy field. Agronomy 2019, 9, 259. [CrossRef]

21. MAPA. Anuarios Estadísticos. Available online: https://www.mapa.gob.es/es/estadistica/temas/publicaciones/anuario-deestadistica/default.aspx (accessed on 18 January 2021). 
22. Cirujeda, A.; Aibar, J.; Zaragoza, C. Remarkable changes of weed species in Spanish cereal fields from 1976 to 2007. Agron. Sustain. Dev. 2011, 31, 675-688. [CrossRef]

23. Marnotte, P. Influence des facteurs agroécologiques sur le developpement des mauvaises herbes en climat tropical humide. In Proceedings of the 1984 7ème Colloque International Ecologie, Biologie et Systematique des Mauvaises Herbes, Paris, France, 9-11 October 1984; COLUMA/EWRS: Paris, France, 1984; pp. 183-188.

24. Alberti, J. L'arròs. Principals Malalties, Plagues i Males Herbes; BASF España: Barcelona, Spain, 1999.

25. Puente, J. Guía de La Flora de La Depresión Del Ebro. Serie Difusión; Consejo Protección de la Naturaleza de Aragón, Gobierno de Aragón: Zaragoza, Spain, 2004.

26. Recasens, J.; Conesa, J.A. Malas Hierbas en Plántula. Guía de Identificación; Universitat de Lleida and Bayer CropScience: Lleida, Spain, 2009.

27. R Core Development Team. R: A Language and Environment for Statistical Computing; R Core Development Team: Vienna, Austria, 2019.

28. Pardo, G.; Marí, A.I.; Aibar, J.; Vilaplana, L.; Cirujeda, A. Bastard Cabbage (Rapistrum rugosum L.) resistance to tribenuron-methyl and iodosulfuron-methyl-sodium in Spain and alternative herbicides for its control. Agronomy 2019, 9, 492. [CrossRef]

29. MAAMA. Guía de Gestión Integrada de Plagas. Cereal. Available online: https:/ /www.mapa.gob.es/es/agricultura/temas/ sanidad-vegetal/GUIAdeCEREALESWEB_tcm30-57956.pdf (accessed on 18 October 2018).

30. Vasconcelos, T.; Forte, P. Weeds in the rice fields of Sado valley. In Proceedings of the VII Congreso de la Sociedad Española de Malherbología, Logroño, Spain, 23-25 November 1999; Suso Martínez de Bujo, M., Pardo Iglesias, A., Eds.; Sociedad Española de Malherbologia: Logroño, Spain, 1999; pp. 394-403.

31. Golmohammadi, M.J.; Mohammaddoust Chamanabad, H.R.; Yaghoubi, B.; Oveisi, M. Rice weed community composition and richness in northern Iran: A temperate rainy area. Appl. Ecol. Environ. Res. 2018, 16, 4605-4617. [CrossRef]

32. FAO. Annexe 1. Crop Salt Tolerance Data. Available online: http://www.fao.org/3/y4263e/y4263e0e.htm (accessed on 21 October 2020).

33. Yuan, Z.Q.; Yu, K.L.; Wang, B.X.; Zhang, W.Y.; Zhang, X.L.; Siddique, K.H.M.; Stefanova, K.; Turner, N.C.; Li, F.M. Cutting improves the productivity of lucerne-rich stands used in the revegetation of degraded arable land in a semi-arid environment. Sci. Rep. 2015. [CrossRef]

34. Carretero, J.L. Flora Arvense Española. Las Malas Hierbas de Los Cultivos Españoles; Phytoma-España: Valencia, Spain, 2004.

35. Hutchinson, I.; Colosi, J.; Lewin, R.A. The biology of Canadian weeds. 63. Sonchus asper (L.) Hill. Biol. Can. Weeds 1984, 64, 731-744. [CrossRef]

36. Hanslin, H.M.; Eggen, T. Salinity tolerance during germination of seashore halophytes and salt-tolerant grass cultivars. Seed Sci. Res. 2005, 15, 43-50. [CrossRef]

37. Pastor Piñero, J.; Hernández, A.J. Old landfills as emergent vulnerable ecosystems to salinization: Soil characteristics and response of the plant species to increasing $\mathrm{Na}$ and anion contents. In Proceedings of the Global Forum on Salinization and Climate Change (GFSCC2010), Valencia, Spain, 25-29 October 2010; pp. 239-248.

38. Lombardi, T.; Fochetti, T.; Onnis, A. Comparative salt tolerance of two wild Hordeum species (H. maritimum With. and H. murinum L.) from the coast of Tuscany (Italy). Plant Biosyst. 2000, 134, 333-339. [CrossRef]

39. Wattl, S.; Vilar, L. A comparative study of the vegetation at Aiguamolls de l'Empordà wetlands (NE Iberian Peninsula). Sci. Gerundensis 1997, 23, 19-154.

40. Turki, Z.; Sheded, M. Some observations on the weed flora of rice fields in the Nile Delta, Egypt. Feddes Repert. 2002, 113, 394-403. [CrossRef]

41. Recasens, J.; Calvet, V.; Cirujeda, A.; Conesa, J.A. Phenological and demographic behaviour of an exotic invasive weed in agroecosystems. Biol. Invasions 2005, 7, 17-27. [CrossRef]

42. Osca, J. Estudio de las malas hierbas más problemáticas de los arrozales valencianos. In Herbologia e Biodiversidade numa Agricultura Sustentável, Proceedings of the XII Congreso da Sociedad Española de Malherbología (SEMh), Lisboa, Portugal, 10-13 November 2009; ISA Press: Lisboa, Portugal, 2009; pp. 289-290.

43. Lewin, R.A. Biological flora of the British Isles. J. Ecol. 1948, 36, 203-233. [CrossRef]

44. Barrett, S.C.H.; Wilson, B.F. Colonizing ability in the Echinochloa crus-galli complex (barnyard grass). I. Variation in life history. Can. J. Bot. 1981, 59, 1844-1860. [CrossRef]

45. Travlos, I.S.; Economou, G.; Kanatas, P.J. Corn and barnyardgrass competition as influenced by relative time of weed emergence and corn hybrid. Agron. J. 2011, 103, 1-6. [CrossRef]

46. Osca, J.M. Expansion of Leptochloa fusca ssp. uninervia and Leptochloa fusca ssp. fascicularis in rice fields in Valencia, eastern Spain. Weed Res. 2013, 53, 479-488. [CrossRef]

47. Vladimirov, V.; Delcheva, M. First record of the alien Diplachne fascicularis (Poaceae) in Bulgaria. Flora Mediterr. 2016, 26. [CrossRef]

48. Lloveras, J.; Melines, M.A. La calidad en la alfalfa. Posibles clasificaciones. Vida Rural 2015, 212, 36-40.

49. MAAMA. Guía de Gestión Integrada de Plagas. Arroz. Available online: https://www.mapa.gob.es/es/agricultura/temas/ sanidad-vegetal/guia_arroz_webprotegida_tcm30-434395.pdf (accessed on 18 October 2018).

50. Reddy, T.Y.; Reddi, G.H.S. Principles of Agronomy, 3rd ed.; Kalyani Publishers: New Delhi, India, 2002.

51. Dass, A.; Shekhawat, K.; Choudhary, A.K.; Sepat, S.; Rathore, S.S.; Mahajan, G.; Chauhan, B.S. Weed management in rice using crop competition-A review. Crop Prot. 2017. [CrossRef] 